\title{
In my life
}

\section{Robert W Tarr}

\begin{abstract}
Though I know I'll never lose affection For people and things that went before I know I'll often think about them In my life I love you more
\end{abstract}

John Lennon and Paul McCartney, 1965

One of the things I've had to adjust to in the past 25 years is the often transitory relationship with people in my work place. At the end of every year a group of residents whom I've worked with for 4 years and a group of fellows whom I've worked with for 1-2 years leave to begin their professional careers. Nurses, technicians, and colleagues from other services also oscillate to and from my work experience. Some of these folks I never see again. Others I may run into occasionally, but I find our relationship has changed. Our personal and work experiences have become disconnected. So our intermittent conversations, while cordial, lack the depth which they once had.

As a defense mechanism, I suppose I have over time built up a bit of a wall between myself and my colleagues at

Correspondence to Dr Robert W Tarr, Department of Radiology, University Hospitals Case Medical Center, 11100 Euclid Ave, Cleveland, OH 44106, USA; robert.tarr@uhhospitals.org work. Perhaps this is for the best. Perhaps it is better that work relations remain a bit distant. I don't know. However, I do know that, because of my wall, there has been a change in my perception of my personal work environment compared to when I first started. The workplace for me seems to lack the spontaneity and fun which it once had.

One area in which my work experience has had little turnover has been the staffing of our neuroradiology section. For the most part the members of our section have worked together for no less than 15 years. Some of the colleagues in my section were residents or fellows in our department when I was a junior staff member. We have witnessed each other's triumphs as well as each other's tribulations, both in our professional and our personal lives.

This month one of my colleagues, Kristine Blackham, is departing from my daily work experience. Kristine is setting sail for a position at a well-respected academic institution in Europe. She is leaving for both professional and personal reasons. I have worked with Kristine for over 14 years while she was a resident, fellow, and finally a staff colleague in our department. She will be missed.
Kristine was nicknamed 'Slow Hand' during her fellowship with us. This is the same moniker by which Eric Clapton is sometimes referred. Similar to Clapton, the nickname was not meant to imply a lack of speed in her work, but rather referred to a smoothness and methodical thoughtfulness by which her work was accomplished.

One of the qualities which Kristine developed most fully during her time with us was her teaching abilities. Kristine has been our fellowship director and has deeply immersed herself in medical student and resident education as well. She has appropriately alternated between a nurturing and an authoritative figure for our trainees as the situation has demanded. As one of my more sardonic colleagues recently put it, "Who is going to beat the residents and fellows into submission once Kristine leaves?”.

So, Kristine, Auf wiedersehen, unsure edelweiss und alles gute.

Competing interests None.

Provenance and peer review Commissioned; internally peer reviewed.

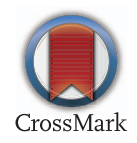

To cite Tarr RW. J Neurolntervent Surg 2015;7:1. Accepted 30 October 2014

J Neurolntervent Surg 2015;7:1. doi:10.1136/neurintsurg-2014-011536 